\title{
The Role of Positive Expectations for Resilience to Adverse Events: Subjective Well-Being Before, During and After the Greek Bailout Referendum
}

\author{
Efstratia Arampatzi ${ }^{1} \cdot$ Martijn Burger ${ }^{1,2} \cdot$ Spyridon Stavropoulos $^{2} \cdot$ Louis Tay $^{3}$
}

Published online: 10 April 2019

(C) The Author(s) 2019

\begin{abstract}
Can positive expectations help foster resiliency against adversity? In this study, we used high-frequency panel data, to examine how positive as compared to neutral and negative expectations can buffer the negative impact on subjective well-being generated by an adverse event, the announcement of the Greek bailout referendum in July 2015. Results show that individuals with more positive expectations for the future before the referendum announcement experienced smaller decreases in subjective well-being and adapted quicker to this adverse event. In addition, we found evidence that individuals who shifted from positive to negative expectations before and during the adverse event, respectively, had significantly lower subjective well-being than individuals who had consistent positive expectations. This finding supports the view that optimism, or consistent positive expectations, and even positive mindsets, as indicated by lacks of shifts to negativity, can be a source of resilience that helps individuals cope and adapt quicker to adverse events.
\end{abstract}

Keywords Positive thinking $\cdot$ Expectations $\cdot$ Subjective well-being $\cdot$ Panel data $\cdot$ Resilience · Adversity

Spyridon Stavropoulos

stavropoulos@ese.eur.nl

Efstratia Arampatzi

arampatzi@ese.eur.nl

Martijn Burger

mburger@ese.eur.nl

http://www.mjburger.net

Louis Tay

stay@purdue.edu

1 Erasmus Happiness Economics Research Organization, Erasmus University Rotterdam, P.O. Box 1738, 3000 DR Rotterdam, The Netherlands

2 Department of Applied Economics, Tinbergen Institute, Erasmus University Rotterdam, P.O. Box 1738, 3000 DR Rotterdam, The Netherlands

3 Purdue University, West Lafayette, USA 


\section{Introduction}

There has been a surge of interest in the role of positive thinking for enhancing resiliency and well-being. In much of the self-help literature, there has been an emphasis placed on the power of positive thinking. For example, the book The Power of Positive Thinking has sold more than 5 million copies in print (Peale 2007). With the advent of positive psychology, this notion has also taken on an increasing quality of truth in the lives of many individuals. Given this, it is important to understand and assess whether promoting and maintaining positive thinking can be protective of well-being.

Empirical evidence that has been drawn on to support the proposal that positive thinking can serve to promote well-being has primarily been through optimism research. Optimism is defined as a dispositional tendency for generalized positive outcomes or positive expectations for the future (Scheier and Carver 1985). More optimistic individuals tend to evaluate disappointing and stressful events more positively (Hecht 2013) and are better able to accept the reality of a situation, especially a situation that is beyond their control. Optimists tend to show more adaptive active coping behavior in that they take a more proactive approach to changing situations that lower their well-being (Scheier et al. 1986). By contrast, pessimists use more maladaptive avoidance coping and tend to avoid coping with the stressful event (Scheier et al. 1986). Hence, positive expectations have an anxiety- and stress-buffering role that helps people remain happy in the wake of adverse events. Moreover, positive expectations can engender positive emotions and better social relations that provide support during times of difficulty (Taylor et al. 2000). In other words, being optimistic can also be regarded as a source of psychological capital or an asset that individuals use to develop adaptive capacities to cope with challenges in life (Carver et al. 2010; Cohn et al. 2009). In this regard, it has been found that resilient people are more positive about the future (Mak et al. 2011).

While there is a rich and robust finding that optimism is associated with, and predictive of, well-being, there is a need to go further to use time-based designs to capture how positive expectations can uphold well-being in the face of negative life events. For example, a past review of longitudinal studies (Scheier and Carver 1992) and more recent studies have focused on the prospective effects of optimism in prediction of well-being outcomes (e.g., Benyamini and Roziner 2008; Boehm et al. 2011) but fewer have examined how positive expectations can buffer well-being in the face of difficult circumstances. Studies that use time-based designs to examine whether well-being is sustained in the face hardship would provide stronger claims associated with the resilience effects of positive expectations. In this regard, Fredrickson et al. (2003) examined the effect of the 9/11 terrorist attack in the USA on the psychological well-being of young adults. Despite the uniform negative effect of this adverse, unexpected event on well-being, young adults who were more optimistic were better able to experience pre-crisis psychological benefits, more frequently experienced positive emotions and coped better with adversity after the attack (Fredrickson et al. 2003). Likewise, health studies have found that more optimistic individuals experience lower decreases in subjective well-being after chemotherapy (Pinquart et al. 2007) or coronary artery bypass surgery (Scheier et al. 1989).

While there are strengths in these ecologically contextualized time-based designs, there are still critical questions of the extent positive expectations exert resilience effects. Foremost, it is now increasingly recognized that the negative thinking is more powerful than the positive thinking due to people's proclivity to loss aversion (Kahneman and Tversky 1979; Tversky and Kahneman 1991), and there is evidence that losses in financial resources have 
a greater impact on well-being than gains (Boyce et al. 2013; De Neve et al. 2018). By extension, positive expectations as a psychological resource may also exhibit the same tendencies. If optimism is the opposite of pessimism, to what extent do positive expectations help protect well-being in the face of adversity as compared to neutral expectations-and to what extent are these effects comparable or different to negative expectations? Past studies have not disentangled these effects and it is difficult to determine if positive expectations (i.e., positive expectations as compared to neutral expectations) or lack of negative expectations (i.e., neutral expectations as compared to negative expectations) are driving protective effects on well-being. In other words, it is important to determine if avoiding negative thinking is driving the effects of resilience as opposed to positive thinking.

Second, past time-based designs have been primarily focused on pre-adversity optimism or positive expectations and their effects on subsequent well-being. While this provides greater resolution for understanding the directional effects of positive expectations on well-being, there is a need to go beyond a snapshot of positive expectations to understand these expectations more dynamically, in the processes before and during adversity. This addresses the critical question of whether maintaining positive expectations is the key to resilience-as viewed from an optimism dispositional lens, or if progressive positive expectations (i.e., having negative or normal expectations before adversity, to having positive ones during) may also have utility for well-being - as viewed from a positivity mindsets lens.

With these two critical issues in mind, our study builds on past time-sensitive studies by using a high-frequency panel data in the face of an adverse ecological event, the Greek bailout referendum in July 2015. Specifically, in this study, we assess the subjective well-being impact of the stress and uncertainty generated by the announcement of the Greek bailout referendum on the subjective well-being of Greek students. In July 2015, Greece experienced one of its most stressful events in recent history as its newly elected government failed to reach an agreement on the bailout terms with its creditors, placing the financial future of the country at risk. The unforeseen announcement of the referendum on the acceptance or rejection of the bailout terms presented a substantial dilemma for Greek citizens Although the majority of Greeks did not approve of the bailout terms set by the Troika (European Commission, European Central Bank and the International Monetary Fund), they also feared exit from the Eurozone (Grexit) and a bankruptcy of Greece. The reinforcement of capital control, limited access to bank accounts, the gloomy prospect of worsening labor markets and liquidity problems, and potential loss of family savings made the bailout referendum announcement an adverse event for most Greeks, who in turn experienced lower subjective well-being. Going beyond past studies that have studied declining subjective well-being in times of crisis (e.g., Di Tella et al. 2003; Gudmundsdottir 2013; Arampatzi et al. 2015, 2019; O'Connor 2017) and around unanticipated nationwide adverse events such as currency devaluations (Hariri et al. 2015), natural disasters (Goebel et al. 2015), and terrorist attacks (Metcalfe et al. 2011; Clark and Stancanelli 2016; Coupe 2017), our goals are to (a) compare the 'power' (i.e., effect size) of positive expectations for well-being during such events; and (b) assessing the role of stability and change in positive thinking during an adverse event for well-being. Our sampled population contains students which has been utilized in past longitudinal studies of optimism successfully (e.g., Brissette et al. 2002). However, we also recognize that additional research is needed to examine to what extent these results hold for the general populations, this exploratory study examining well-being in the wake of an important and complicated historical event (the bailout crisis) provides a good setting to study the mitigating role of positive thinking. 


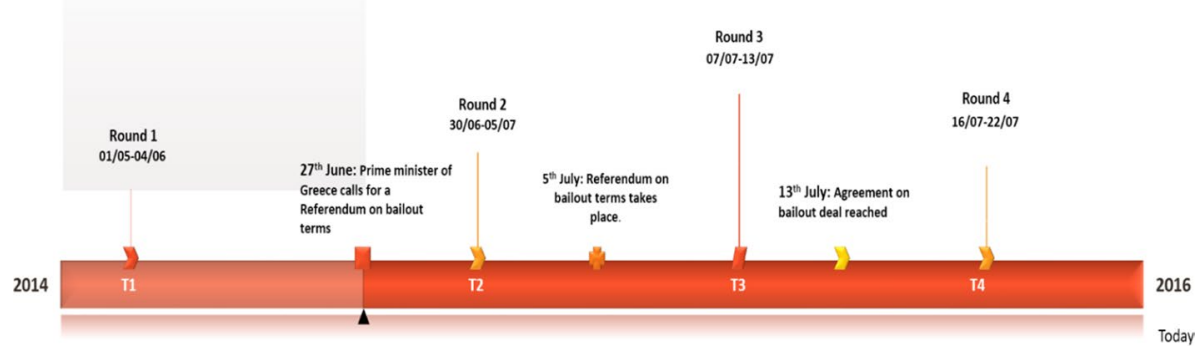

Fig. 1 Data collection surrounding the Greek Bailout Referendum in 2015. Note: The first wave occurred between May 4 and June 4 when the economic and political situation in Greece was relatively stable (Wave 1). Immediately after the failure to reach an agreement with the creditors, the prime minister called Greek citizens to determine the bailout terms and announced the referendum on June 27. The second wave of data collection started on June 30 and concluded on July 5 (Wave 2). Although the majority of the Greek people rejected the bailout terms on July 5, the negotiations continued for several days, and the reinforcement of capital controls in the banking system generated liquidity problems, additional uncertainty regarding financial institutions, especially in family savings, payments and transactions. Wave 3 occurred after the announcement of the results and during the reinforcement of capital controls between July 7 and 13 (Wave 3 ). Wave 4 signals the termination of negotiations on July 13, when the final agreement was also made and the financial threat was eliminated (July 16-22) (Wave 4)

\section{Method}

\subsection{Participants}

To examine the buffering effect of positive expectations, we utilize survey data ${ }^{1}$ collected at Greek universities in the period May 2015-July 2015 using convenience sampling. The data were collected before (Wave 1), during (Waves 2 and 3) and after (Wave 4) the Greek bailout referendum (see Fig. 1). ${ }^{2}$ More specifically, students were approached in May 2015 and asked to complete a survey on the state of Greece and their own personal situation. The survey was promoted at Greek universities across the country, predominantly at the Aristotle University of Thessaloniki, University of Macedonia, University of Patras, and University of Piraeus, and via social media. Overall, 1276 students started the first survey, of which 1163 students finished the complete survey. Of the initial 1163 participants in the sample, $71 \%$ were female, while the average age was 22.5 years old. Most participants studied at the University of Macedonia in Thessaloniki (23\%), University of Patras (19\%), Aristotle University in Thessaloniki (17\%), and University of Piraeus (9\%). The study participants included students from different disciplines, including economics (23\%), business administration (9\%), social and political sciences (16\%), natural sciences and engineering (14\%), educational studies (8\%), computer science (7\%), and medicine (4\%). The students

\footnotetext{
1 We conducted an online survey. The survey was completed anonymously, herewith ensuring confidentiality. Our online survey did not need to be reviewed by a research ethics committee (REC).

2 The original aim of the study was to study the happiness of Greek students in time of economic and political crisis. A follow-up study was planned, but due to the announcement of the referendum, the study was carried out earlier than originally anticipated.
} 
were equally divided across the different years of their study. In the January 2015 election, most respondents indicated they voted for SYRIZA (30\%; radical left political party), Nea Dimokratia (14\%; liberal-conservative political party), and To Potami (10\%; centrist and social-liberal political party).

The students in the first survey who provided their e-mail addresses received invitations by e-mail in July to complete a web-based questionnaire on the following three occasions: (1) 3 days after the announcement of the Greek referendum (Wave 2), (2) 2 days after the referendum (Wave 3), and (3) 3 days after an agreement with the Troika was reached (Wave 4). In total, 284, 190, and 162 students participated in the three additional waves. Although our sample is not-representative of the Greek (student) population, convenience sampling was the only viable option to study this special historical situation, especially given the lack of good panel data within Greece. These limitations are further touched upon in the discussion section.

\subsection{Measures}

Subjective well-being, defined as "the degree to which an individual judges the overall quality of his/her own life-as-a-whole favorably" (Veenhoven 1984), was measured using an 11-point scale measure of happiness based on the following question: "Taking all things together, how happy would you say you are?" [(0) Not happy at all; (10) Very happy]. In all four waves, the happiness question was asked at the beginning of the questionnaire. This happiness question used to measure subjective well-being has been frequently employed in earlier happiness economics studies due to its inclusion in the European Social Survey. Most happiness economics studies have used single-item measures, which have been proven to be adequately reliable and valid (Diener et al. 2013) and perform relatively well as compared to multi-item scales like Diener's Satisfaction with Life Scale, albeit with lower reliabilities (see also Schimmack and Oishi 2005).

In order to measure respondents' expectations, we use several self-report measures. A first set of questions participants were only answered in the first wave of the study before the bailout referendum announcement: "What are your expectations for the year to come: will the next 12 months be better, worse or the same when it comes to... (1) your life in general, (2) the financial situation of your household, (3) your personal job situation, (4) the employment situation in Greece, and (5) the economic situation in Greece". Respondents choose between "Worse", "Same", and "Better". Based on these five single-item measures, an expectations index ranging from 1 (all components: "Worse") to 3 (all components: "Better") was created. ${ }^{3}$ Cronbach's alpha (0.79) indicated that the index is internally consistent. These questions are used to examine (1) whether more positive expectations and (2) whether positive expectations or the lack of negative expectations are driving resilience effects.

In this research, we are also interested whether we it are specifically people with consistent positive expectations, as indicated by lacks of shifts to negativity, over time that are resilient. Unfortunately, the different items on the expectations index were measured only in the first wave of the research. However, one comparable question related to expectations in the job market was included in both Waves 1 and 2: "Some analysts say that the

\footnotetext{
3 The index is the average of the available items. Availability of at least three out of five items was the eligibility criterion for the construction of the index.
} 
Table 1 Descriptive statistics: participation in the survey

\begin{tabular}{|c|c|c|c|c|}
\hline Participation and response rates & $\mathrm{N}$ & Total drop-out $\mathrm{N}$ & $\begin{array}{l}\text { Response rate (\% } \\
\text { of total remaining } \\
\text { sample) }\end{array}$ & $\begin{array}{l}\text { Remaining } \\
\text { Respondents ( } \% \text { of } \\
\text { first wave) }\end{array}$ \\
\hline First wave & 1163 & 879 & & \\
\hline First and second wave & 284 & 84 & $24.4 \%$ & $24.4 \%$ \\
\hline First, second, and third wave & 190 & 38 & $66.9 \%$ & $16.3 \%$ \\
\hline All waves & 162 & & $85.3 \%$ & $13.9 \%$ \\
\hline
\end{tabular}

impact of the economic crisis on the job market has already reached its peak and things will recover little by little. Others, on the contrary, say that the worst is still to come. Which of these two statements is closer to your opinion? (1) The impact of the crisis on jobs has already reached its peak. (2) The worst is still to come. (3) Don't know". Whereas the first answer category denotes more positive expectations regarding developments in the job market, the second category reflects a more negative outlook. Although a neutral answer category is lacking, we can examine the effect of shifts to negativity over time by considering respondent answers in both Waves 1 and 2.

Finally, we included several control variables that could confound the relationship between expectations and change in subjective well-being in our econometric analysis. These variables include socio-demographic and personality characteristics of the individuals as well as political preferences and recent voting behavior. In addition to standard sociodemographic characteristics, such as age, gender, location of residence, health, income, and marital status, respondents had to answer questions with respect to the frequency of meeting friends, propensity to trust other people, and their religiosity. In terms of personality, the Big Five personality traits (neuroticism, extraversion, openness, agreeableness, and conscientiousness) were measured using a 10-item inventory (Gosling et al. 2003). Political preferences of the respondents were captured by asking about their voting behavior during the last elections. A detailed description, summary statistics and the correlation matrix of the variables included in the analysis can be found in Tables 6, 7 and 8 in "Appendix 1".

\subsection{Data Checks}

Given the longitudinal design, a potential caveat is that our data might suffer from selection bias and panel attrition bias. Attrition bias arises if respondents drop out for the panel nonrandomly, namely, when attrition is interrelated with a variable of interest. Table 1 shows the sample size of each wave of our survey, dropout data and the respective participation rate. We examine panel attrition bias using the demographic data, levels of expectations, and happiness scores of the students that were obtained in the first questionnaire.

Using logistic regression, we compared the students who completed all four waves of questions and the students who dropped out of the survey during or after Wave 1, Wave 2, or Wave 3. The results are presented in Table 2, while socio-demographic characteristics of the respondents in the four waves are provided in Table 9 in "Appendix 1". The levels of happiness or expectations at Wave 1 did not differ significantly between individuals who 
Table 2 Self-selection in sample — participation in all rounds versus only first round-marginal effects

(1)

\begin{tabular}{lc}
\hline Happiness (Wave 1) & -0.007 \\
Expectations index (5 domains) & $(0.007)$ \\
Male & -0.011 \\
& $(0.020)$ \\
Age & $0.049^{* *}$ \\
Living with parents (same household) & $(0.024)$ \\
& $0.013^{* * *}$ \\
Frequency meeting friends (reference: several times per week) & $(0.003)$ \\
Once per week/Several times a month & $0.057^{* * *}$ \\
& $(0.022)$ \\
Once per month/never & $-0.051^{* * *}$ \\
Program (reference: other) & $(0.024)$ \\
Economics, business administration, and political science & -0.042 \\
Observations & $(0.027)$
\end{tabular}

Model has been estimated using logistic regression; only significant coefficients and coefficients of main variables of interest displayed

Robust standard errors in parentheses

$* * * p<0.01, * * p<0.05, * p<0.1$

participated in all four waves and those who did not participate in all four waves. Hence, we conclude that the selection effect with regard to our main variables of interest is limited. However, respondents who were older or male, who lived with their parents at the time of the interview, who saw their friends often and who were studying economics, business administration and/or political science were more likely to complete all four waves of the survey.

\section{Results}

\subsection{Descriptive Statistics and Preliminary Analyses}

Overall, young adults in our sample report an average happiness of 7.10 on a 10-point scale (Wave 1, common sample). This score for our sample is higher than other subjective wellbeing figures that have been reported in large-scale annual surveys for Greece. For instance, the Eurobarometer of March 2015 reports an average life satisfaction of 2.33 out of 4 for Greece, ${ }^{4}$ while the Gallup World Poll 2014 reports an average life satisfaction score of 4.8

\footnotetext{
4 The item measured by Eurobarometer is a 4-item life satisfaction indicator. European Commission, Brussels (2014): Eurobarometer 80.1 (2013). TNS Opinion, Brussels [producer]. GESIS Data Archive, Cologne. ZA5876 Data file Version 1.0.0, https://doi.org/10.4232/1.11881. The question reads: "On the whole, are
} 
out of 10 for Greece using the Cantril ladder question (scale 0-10). ${ }^{5}$ At the same time, an examination of the Eurobarometer micro-data shows that Greek students are substantially more satisfied than other parts of the Greek population. The Eurobarometer of March 2015 report an average life satisfaction score of 2.77 points (66\% satisfied) for students and 2.29 points (45\% satisfied) for non-students. Along similar lines, young people (younger than 25 years) in Greece that are out of the workforce scored in the Gallup World Poll of 2014 a 7.0 out of 10 on the Cantril Ladder. Overall, Greek students appear to report being happier or more satisfied than the general population prior the referendum announcement. ${ }^{6}$

Starting with a visual inspection of the data, Fig. 2 presents average happiness scores ${ }^{7}$ for three distinct expectations groups (predominantly worse, predominantly same, predominantly better) created by the distribution of the expectations index and for the three answer category groups (worse, same, better) for the five domains on which the index was based. Index groups were constructed in the following way: predominantly worse expectations 1.5 or lower; predominantly same expectations $>1.5$ but $<2.5$; high expectations 2.5 or higher (see Fig. 3).

In Wave 1, average happiness scores differ slightly between individuals with different levels of expectations. The average for respondents who scored high on expectations is 0.77 points higher than the average for those with low expectations. The happiness of individuals who scored predominantly worse on the expectations index at Wave 1 decreased by 2.2 points (on a 10-item scale), which is a much larger decrease than that for individuals with predominantly similar or predominantly better expectations, whose happiness decreased by 1.78 and 1.18 points, respectively. On average, happiness levels declined by 1.77 points in the wake of the announcement of the bailout referendum and rose again to an average of 6.27 after the final agreement. The pattern is consistent for all five expectations items in Fig. 2.

In addition to the finding that individuals with more positive expectations reported slightly higher happiness levels prior to the Greek bailout referendum, two observations are noteworthy. First, individuals with more positive expectations experienced a smaller decrease in happiness between the time of the first survey and the time of the Greek bailout referendum announcement. Second, compared with those with lower expectations, individuals with more positive expectations recovered their original happiness level must faster between the time of the announcement and the time that the new deal with the European Union and IMF was made. Again, this general pattern is observed for the overall expectation index as well as for each element of the expectations index. This appears to generally support the idea that positive expectations serve to buffer adverse event effects on subjective well-being.

Footnote 4 (continued)

you very satisfied, fairly satisfied, not very satisfied, or not at all satisfied with the life you lead?" Possible answers are (1) Not at all satisfied, (2) Not satisfied, (3) Fairly satisfied, and (4) Very satisfied. People are considered satisfied if they report (3) Fairly satisfied, or (4) Very satisfied.

5 The Cantril ladder question asks on which step of the ladder, with steps from 0 to 10 , a person feels he or she stands at present. The higher the score on the ladder, the closer one's life is seen to his or her ideal life.

6 At the same time, students in our sample indicated they were affected by the current crisis. Of the participants in the first wave, $30 \%$ indicated that a family member lost their job as a direct consequence of the crisis. In addition, well over $80 \%$ of the respondents indicated they had to manage on a lower personal income and holidays as a direct consequence of the crisis. Job market prospects/unemployment and the economic situation were most often mentioned by the respondents as the main issues they were currently facing. Almost all participants (98\%) agreed that the crisis has had a significant on the Greek economy.

7 Figure 2 was produced based on the common sample for all periods. 
Expectations Index

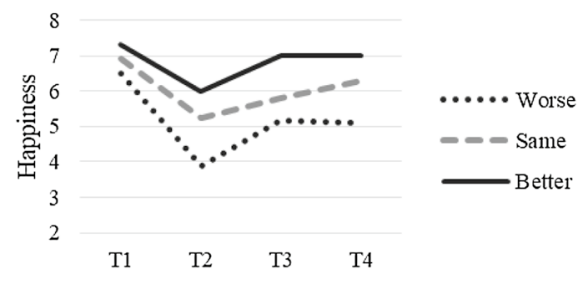

Financial Situation Household

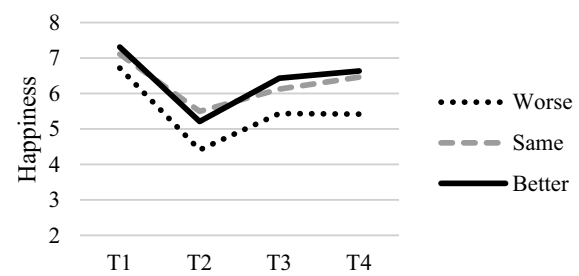

Employment Situation in Greece

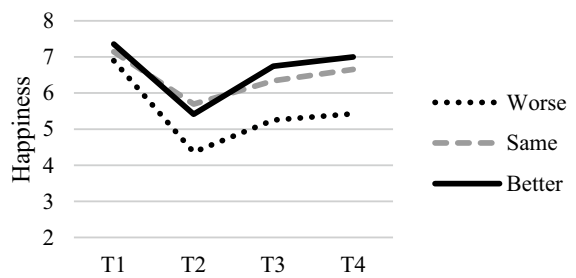

Life in General

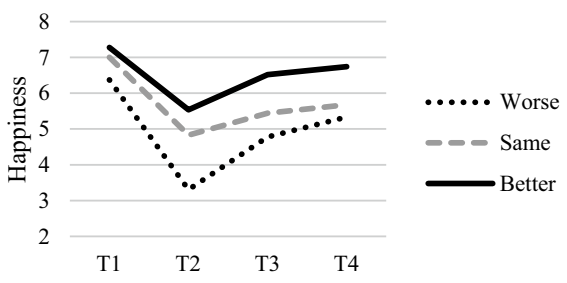

Personal Job Situation

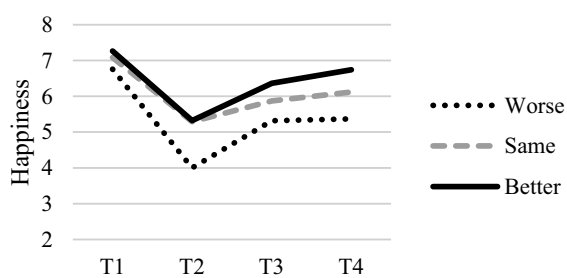

Economic Situation in Greece

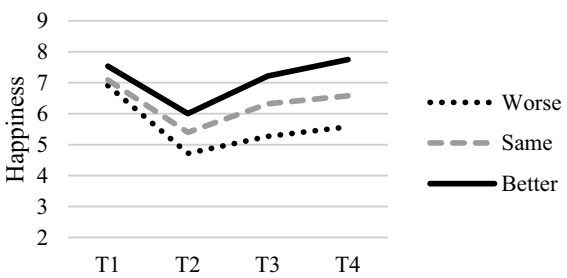

Fig. 2 Happiness trends by expectations. Note: The graphs refer to reported expectations based on the following question: What are your expectations for the year to come: will the next 12 months be better, worse or the same, when it comes to... (1) your life in general, (2) the financial situation of your household, (3) your personal job situation, (4) the employment situation in Greece, and (5) the economic situation in Greece". The construction of the expectations index is discussed in the main text

Fig. 3 Expectations index

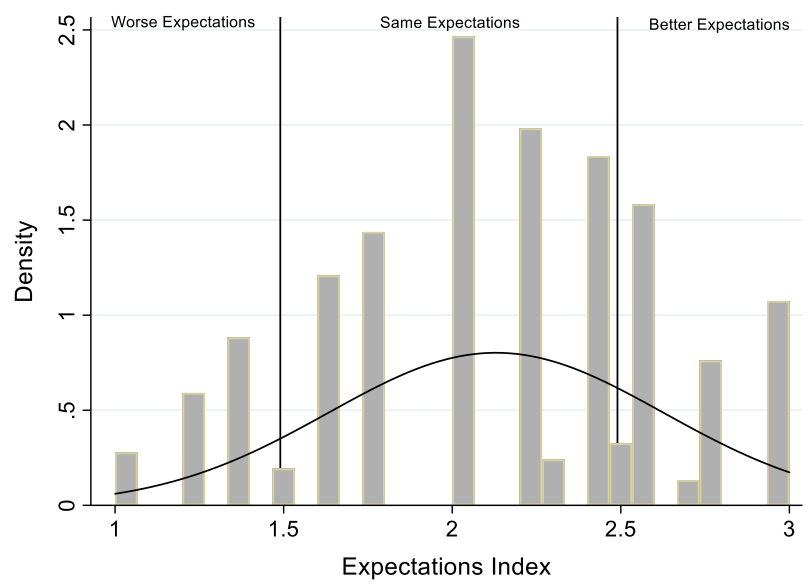




\subsection{Regression Analysis}

To conduct statistical inference on the visualized trends, we specify a simple reduced-form happiness model (see also Di Tella et al. 2003; Frey et al. 2009) to examine the relationship between expectations and changes in subjective well-being:

$$
\delta S W B_{j t}=\vartheta \text { Expectations }_{j 1}+\omega \text { Personal }_{j 1}+\rho S W B_{j t-1}+\mu_{j t}
$$

where $\delta S W B_{j t}$ denotes the difference in a self-report measure of subjective well-being scores for individual $j$ between waves. $\vartheta$ Expectations $_{j}$ is a (vector of) self-report measure(s)

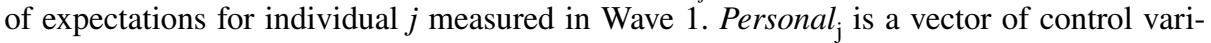
ables related to personal and sociodemographic characteristics (age, gender, marital status, frequency of social contacts, social trust, religion, health, personality traits and political preferences) and socio-demographic characteristics (self-reported amount of monthly expenses, household situation) and demographics (age, gender and marital status) of individual $j, S W B_{\mathrm{jt}-1}$ the reported subjective well-being in the previous wave, and $\mu_{\mathrm{jt}}$ is a residual error.

In this model, we examined (a) the differences in subjective well-being between Wave 1 (situation before the announcement of the Greek bailout referendum) and Wave 2 (situation immediately after the announcement of the referendum) and (b) the differences in subjective well-being between Waves 2 and 4 (situation immediately after the deal with the Trojka) to test whether positive expectations are associated with resilience; that is, a smaller decrease in subjective well-being in the wake of an adverse event and a faster pace in bouncing back to the original level of subjective well-being.

\subsubsection{The Effect of Positive Expectations}

The pattern observed from a simple visual inspection is reproduced by the estimated OLS in Table 3. Controlling for the previous level of subjective well-being as well as personal and socio-economic characteristics of the respondents, we find that the expectations index is positively and significantly associated with the difference in happiness between Waves 1 and 2 (Table 3; Columns 1 and 2). On average, individuals with better future expectations (higher scores on the expectations index) before the announcement experienced a smaller decrease in subjective well-being between these time points than other individuals did. Directly comparing our regression results to the results in Fig. 2, we find that individuals who belong to the 75th percentile on the expectations index experienced a smaller decrease between Waves 2 and $1(b=0.76, p<0.01)$ than did individuals on the bottom of the distribution of the expectation index. ${ }^{8}$ Additionally, when examining the development of happiness between Waves 2 and 4, we find that individuals who scored higher on the expectations index also reported a significantly larger increase in subjective well-being (Table 3; Columns 3 and 4). ${ }^{9}$ The respective comparison of the groups shows that respondents within the 75 th percentile of the distribution of the expectations index reported a

\footnotetext{
${ }^{8}$ Estimates are produced by using the ordinal measure of expectations index, as shown in Fig. 1, and are available upon request.

9 The sensitivity of our results regarding various time references is shown in Table 10 in "Appendix 2". Here, we focus again on the 5-item expectations index, which is explored using the happiness differences between Waves 4 and 3, between Waves 3 and 2 and between Waves 3 and 1. High expectations index scores are positively associated with differences in happiness in all periods showing the mitigating effect of expectations during stressful events and recovery periods.
} 
Table 3 OLS and Lewbel estimations on expectations and changes in subjective well-being

\begin{tabular}{|c|c|c|c|c|}
\hline & \multicolumn{2}{|c|}{$\begin{array}{l}\text { Difference in happiness Wave } \\
2 \text { - Wave } 1\end{array}$} & \multicolumn{2}{|c|}{$\begin{array}{l}\text { Difference in happiness Wave } \\
4 \text { - Wave } 2\end{array}$} \\
\hline & OLS & Lewbel estimator & OLS & Lewbel estimator \\
\hline Expectations index (5 domains) & $\begin{array}{l}0.824 * * * \\
(0.297)\end{array}$ & $\begin{array}{l}1.535 * * \\
(0.650)\end{array}$ & $\begin{array}{l}0.763 * * * \\
(0.268)\end{array}$ & $\begin{array}{l}0.664 * \\
(0.352)\end{array}$ \\
\hline Male & $\begin{array}{l}0.233 \\
(0.288)\end{array}$ & $\begin{array}{l}0.275 \\
(0.283)\end{array}$ & $\begin{array}{l}-0.424 \\
(0.273)\end{array}$ & $\begin{array}{l}-0.550 * * * \\
(0.058)\end{array}$ \\
\hline Age & $\begin{array}{l}-0.062 * \\
(0.033)\end{array}$ & $\begin{array}{l}-0.055^{*} \\
(0.033)\end{array}$ & $\begin{array}{l}-0.071^{* *} \\
(0.031)\end{array}$ & $\begin{array}{l}-0.426 \\
(0.263)\end{array}$ \\
\hline Married & $\begin{array}{l}0.803 \\
(0.817)\end{array}$ & $\begin{array}{l}0.700 \\
(0.861)\end{array}$ & $\begin{array}{l}0.080 \\
(1.486)\end{array}$ & $\begin{array}{l}-0.070 * * \\
(0.028)\end{array}$ \\
\hline Separated & $\begin{array}{l}-0.040 \\
(0.946)\end{array}$ & $\begin{array}{l}-0.021 \\
(1.094)\end{array}$ & - & $\begin{array}{l}0.185 \\
(1.356)\end{array}$ \\
\hline Single & $\begin{array}{l}-0.251 \\
(0.276)\end{array}$ & $\begin{array}{l}-0.297 \\
(0.265)\end{array}$ & $\begin{array}{l}-0.405 \\
(0.256)\end{array}$ & - \\
\hline Living with parents (same household) & $\begin{array}{l}0.329 \\
(0.308)\end{array}$ & $\begin{array}{l}0.412 \\
(0.294)\end{array}$ & $\begin{array}{l}0.328 \\
(0.256)\end{array}$ & $\begin{array}{l}-0.362 \\
(0.226)\end{array}$ \\
\hline Month expenses: $€ 300-499$ & $\begin{array}{l}-0.048 \\
(0.385)\end{array}$ & $\begin{array}{l}-0.119 \\
(0.371)\end{array}$ & $\begin{array}{l}0.395 \\
(0.352)\end{array}$ & $\begin{array}{l}0.332 \\
(0.231)\end{array}$ \\
\hline Month expenses: above $€ 500$ & $\begin{array}{l}0.293 \\
(0.477)\end{array}$ & $\begin{array}{l}0.416 \\
(0.463)\end{array}$ & $\begin{array}{l}0.572 \\
(0.442)\end{array}$ & $\begin{array}{l}0.407 \\
(0.315)\end{array}$ \\
\hline Physical or mental health problem: Yes & $\begin{array}{l}0.461 \\
(0.661)\end{array}$ & $\begin{array}{l}0.480 \\
(0.608)\end{array}$ & $\begin{array}{l}-0.257 \\
(0.706)\end{array}$ & $\begin{array}{l}0.566 \\
(0.404)\end{array}$ \\
\hline \multicolumn{5}{|l|}{ Frequency meeting friends } \\
\hline Once per week/Several times a month & $\begin{array}{l}-0.328 \\
(0.313)\end{array}$ & $\begin{array}{l}-0.291 \\
(0.301)\end{array}$ & $\begin{array}{l}-0.247 \\
(0.289)\end{array}$ & $\begin{array}{l}-0.329 \\
(0.622)\end{array}$ \\
\hline Once per month/Never & $\begin{array}{l}-0.620^{*} \\
(0.353)\end{array}$ & $\begin{array}{l}-0.588^{*} \\
(0.335)\end{array}$ & $\begin{array}{l}0.328 \\
(0.346)\end{array}$ & $\begin{array}{l}-0.260 \\
(0.263)\end{array}$ \\
\hline Trust in people & $\begin{array}{l}-0.027 \\
(0.062)\end{array}$ & $\begin{array}{l}-0.042 \\
(0.060)\end{array}$ & $\begin{array}{l}0.038 \\
(0.066)\end{array}$ & $\begin{array}{l}0.319 \\
(0.316)\end{array}$ \\
\hline Voting behavior: Syriza & $\begin{array}{l}0.987 * * * \\
(0.283)\end{array}$ & $\begin{array}{l}0.904 * * * \\
(0.279)\end{array}$ & $\begin{array}{l}-0.318 \\
(0.267)\end{array}$ & $\begin{array}{l}0.040 \\
(0.060)\end{array}$ \\
\hline Voting behavior: denied & $\begin{array}{l}0.219 \\
(0.445)\end{array}$ & $\begin{array}{l}0.147 \\
(0.452)\end{array}$ & $\begin{array}{l}0.175 \\
(0.305)\end{array}$ & $\begin{array}{l}-0.320 \\
(0.244)\end{array}$ \\
\hline Religious & $\begin{array}{l}-0.125 \\
(0.292)\end{array}$ & $\begin{array}{l}-0.193 \\
(0.282)\end{array}$ & $\begin{array}{l}0.295 \\
(0.255)\end{array}$ & $\begin{array}{l}0.201 \\
(0.282)\end{array}$ \\
\hline Neuroticism & $\begin{array}{l}-0.065 \\
(0.057)\end{array}$ & $\begin{array}{l}-0.031 \\
(0.061)\end{array}$ & $\begin{array}{l}-0.036 \\
(0.058)\end{array}$ & $\begin{array}{l}0.295 \\
(0.232)\end{array}$ \\
\hline Extraversion & $\begin{array}{l}-0.002 \\
(0.054)\end{array}$ & $\begin{array}{l}0.006 \\
(0.052)\end{array}$ & $\begin{array}{l}0.006 \\
(0.044)\end{array}$ & $\begin{array}{l}-0.045 \\
(0.056)\end{array}$ \\
\hline Openness & $\begin{array}{l}-0.060 \\
(0.064)\end{array}$ & $\begin{array}{l}-0.058 \\
(0.063)\end{array}$ & $\begin{array}{l}0.001 \\
(0.047)\end{array}$ & $\begin{array}{l}0.005 \\
(0.040)\end{array}$ \\
\hline Agreeableness & $\begin{array}{l}0.069 \\
(0.067)\end{array}$ & $\begin{array}{l}0.099 \\
(0.064)\end{array}$ & $\begin{array}{l}0.028 \\
(0.067)\end{array}$ & $\begin{array}{l}0.008 \\
(0.042)\end{array}$ \\
\hline
\end{tabular}


Table 3 (continued)

\begin{tabular}{|c|c|c|c|c|}
\hline & \multicolumn{2}{|c|}{$\begin{array}{l}\text { Difference in happiness Wave } \\
2-\text { Wave } 1\end{array}$} & \multicolumn{2}{|c|}{$\begin{array}{l}\text { Difference in happiness Wave } \\
4-\text { Wave } 2\end{array}$} \\
\hline & OLS & Lewbel estimator & OLS & Lewbel estimator \\
\hline \multirow[t]{2}{*}{ Conscientiousness } & 0.088 & 0.077 & 0.095 & 0.033 \\
\hline & $(0.082)$ & $(0.080)$ & $(0.070)$ & $(0.061)$ \\
\hline \multirow[t]{2}{*}{ Non-economics, BA, political science } & -0.025 & -0.003 & 0.103 & 0.107 \\
\hline & $(0.315)$ & $(0.308)$ & $(0.291)$ & $(0.265)$ \\
\hline Happiness Wave 1 & $\begin{array}{l}-0.591 * * * \\
(0.091)\end{array}$ & $\begin{array}{l}-0.592 * * * \\
(0.088)\end{array}$ & - & \\
\hline Happiness Wave 2 & - & & $\begin{array}{l}-0.562^{* * * *} \\
(0.062)\end{array}$ & $\begin{array}{l}-0.550 * * * \\
(0.058)\end{array}$ \\
\hline \multirow[t]{2}{*}{ Constant } & 1.500 & -0.619 & $2.763 *$ & $2.864^{*}$ \\
\hline & $(1.568)$ & $(1.897)$ & $(1.667)$ & $(1.719)$ \\
\hline Location dummies & Yes & Yes & Yes & Yes \\
\hline $\begin{array}{l}\text { Kleibergen-Paap rk LM statistic ( } p \\
\text { value) }\end{array}$ & & 0.000 & & 0.000 \\
\hline Kleibergen-Paap rk Wald F statistic & & 13.954 & & 8.773 \\
\hline $\begin{array}{l}\text { Stock-Yogo } 10 \% \text { maximal IV relative } \\
\text { bias }\end{array}$ & & 10.270 & & 9.080 \\
\hline Hansen $\mathrm{J}$ statistic ( $p$ value) & & 0.496 & & 0.729 \\
\hline Observations & 284 & 284 & 162 & 162 \\
\hline R-squared & 0.265 & 0.247 & 0.521 & 0.520 \\
\hline
\end{tabular}

Please note that the Kleibergen-Paap rk Wald F statistic indicates for model 2 that instruments are slightly weak since Stock-Yogo criterion is not met

Robust standard errors in parentheses

$* * * p<0.01, * * p<0.05, * p<0.1$

larger increase between Waves 2 and $4(b=1.038, p<0.01)$ than did respondents in the first quantile (25th percentile).

From our regressions, some other results merit discussion. First, respondents who voted for Tsipras' SYRIZA party during the last elections and who were more likely to be in favor of the bailout referendum experienced a much smaller decreases in subjective wellbeing than did respondents who voted for another political party during the last elections. Hence, respondents who were more likely to be in favor of the bailout referendum experienced smaller declines in subjective well-being. Second, people who were more likely to receive social support in terms of social contacts experienced smaller decreases in subjective well-being. In this regard, social support can also buffer the adverse effects of a shock. Third, although our sample is generally homogenous in terms of age, younger people also appeared to be more likely to experience smaller decreases in subjective well-being after the announcement. An explanation for this result is that younger respondents have less financial independence than older students and are not yet close to entering the labor market; therefore, younger respondents are less likely to be affected by unfavorable developments in the market. Fourth, happier people experienced larger declines in well-being between Waves 1 and 2. Although we might have expected that happier people would be more resilient, the limited dependent nature of the happiness response scale (ranging from 
0 to 10) could contribute to the finding that absolute declines in happiness are greater for happier people.

\subsubsection{Reverse Causality}

To address possible endogeneity issues caused by the simultaneous determination of dependent and independent variables and constrained by the limited availability of valid instruments, we apply an instrumental variable estimation with heteroskedasticity-based instruments for cross-sectional data, also known as the Lewbel IV estimator (see e.g., Lewbel 2012). The Lewbel IV estimator uses internally generated instruments comparable to difference generalized method of moments (GMM) and system GMM in a panel data setting to isolate the effect of expectations on changes in subjective well-being. Following Lewbel (2012), in the absence of instrumental variables, a vector of exogenous variables $Z$ equal to a set of independent variables $X$ or a subset of $X$ can be used to generate external instruments $[\mathrm{Z}-\mathrm{E}(\mathrm{Z})] \varepsilon,{ }^{10}$ given that (1) there is some heteroskedasticity in the standard errors $\varepsilon$ and $(2) \mathrm{E}(\mathrm{X} \varepsilon)=0$ and $\operatorname{cov}(\mathrm{Z}, \varepsilon) \neq 0$. $^{11}$

Columns 3 and 4 in Table 3 show the Lewbel IV estimates. Our results confirm the resilience-generating capacities of positive expectations, and they are validated when we account for reverse causality using a Lewbel estimator, showing that better expectations for the future significantly predict differences in the development of subjective well-being for both periods. $^{12}$

\subsubsection{Positive Versus Neutral and Negative Expectations}

Next, we examine whether positive expectations or lack of negative expectations are driving resilience effects. In order to do so, we added a quadratic term for the expectations index in the baseline model to see if the association of positive expectations with change in happiness had a non-linear component. If indeed a non-linear component is present, this might indicate that the lack of negative expectations (i.e., having neutral or positive

\footnotetext{
10 A more detailed account of how the instruments are estimated can be found in the work of Lewbel (2012).

11 As the validity of these assumptions for our data could be questioned, we first examine whether the Lewbel requirements are met for the regression model. First, we test for the presence of heteroskedasticity. In line with the work of Lewbel (2012), we performed a Breusch-Pagan Lagrange Multiplier Test. The results show that the Breusch-Pagan Lagrange Multiplier Test statistic is significantly different from zero in all regressions, indicating that the variance in our data is sufficient to avoid the creation of weak instruments. Second, before estimating the second stage of the regressions using the generated instruments, we carefully consider the choice of instruments. As indicated by Lewbel (2012), the vector of exogenous variables can be a subset of the independent variables $\mathrm{X}$, and therefore, the obtained estimates could be largely dependent on the specific choice of these variables. In general, the choice of exogenous variables can be random, subject to the conditions above, we opted to follow a different strategy to select our instruments. Our strategy for choosing $\mathrm{Z}$ is based on the correlation matrix of the generated instruments. The subset of $\mathrm{X}$ had to satisfy two basic conditions: (1) it had to be uncorrelated with the dependent variable, and (2) it had to be statistically correlated with the independent variable of interest. The generated instruments that did not meet these conditions were omitted from the second-stage regression. After testing whether the conditions were satisfied (based on the Hansen J test and Stock-Yogo weak ID test), we chose a set of instruments and estimated the model using GMM. In the regression tables, we report both the OLS and Lewbel IV estimates.

12 When we exclude the item related to expectations with regard to life in general in our index, which can alternatively be perceived as an overall evaluation, we reach similar conclusions. These results are available upon request.
} 
Table 4 OLS estimations on expectations and changes in subjective well-being: non-linear effects

\begin{tabular}{lll}
\hline & $(1)$ & $(2)$ \\
& $\begin{array}{l}\text { Change in hap- } \\
\text { piness Wave } \\
2-\text { Wave } 1\end{array}$ & $\begin{array}{l}\text { Change in hap- } \\
\text { piness Wave } \\
4-\text { Wave 2 }\end{array}$ \\
\hline Expectations index (5 & $0.792^{* * *}$ & $0.730 * * *$ \\
domains; mean-centered) & $(0.291)$ & $(0.264)$ \\
Expectations index squared & -0.798 & -0.331 \\
Control variables & $(0.508)$ & $(0.456)$ \\
Observations & Yes & Yes \\
R-squared & 284 & 162 \\
\hline
\end{tabular}

expectations) instead of positive expectations drive the resilience-generating effect. Table 4 shows the OLS estimations including the quadratic term for the expectations index. ${ }^{13}$ Although we find for both periods a negative coefficient for the quadratic term, the coefficient is statistically insignificant, indicating that positive expectations rather than the lack of negative expectations drive the generation of resilience in the wake of the announcement of the Greek bailout referendum.

As a robustness check, we examined the effects of the five expectations components on change in happiness independently. The constructed index used thus far as a proxy for expectations captures well several aspects related to economic expectations at the individual and national levels and expectations for life in general. The OLS results (see Tables 11, 12 in "Appendix 2") show a mitigating effect of positive expectations during stressful events and recovery periods, where the most evident mitigating effects hold for expectations regarding individual domains, including expectations regarding life in general, the financial situation of the household, and personal job situation.

The results also show that between Waves 1 and 2, the group that initially held more neutral expectations only experienced a larger decline in well-being between compared to the group that expected a (predominantly) positive future with regard to life in general domain $(b=0.62, p=0.02)$, but not with regard to the other domains. In none of the regressions, respondents with neutral expectations experienced a significantly lower decrease in happiness compared to respondents with positive expectations regarding the future. Focusing on the recovery period (Waves $2-4$ ), we find that the group that initially held more neutral expectations experienced a smaller recovery in well-being between compared to the group that expected a (predominantly) positive future in three different domains: life in general $(b=0.85, p<0.01)$, personal job situation $(b=0.58, p=0.04)$, and the economic situation in the country $(b=1.04, p<0.01)$. Accordingly, we conclude that positive expectations rather than the lack of negative expectations that are driving resilience-generating effects on well-being.

\footnotetext{
${ }^{13}$ In these estimations, the expectations variable was mean centered to remedy potential multicollinearity problems.
} 
Table 5 Labor market expectations at Wave 1 and 2 and change in happiness-OLS estimates

\begin{tabular}{lllll}
\hline & $(1)$ & $(2)$ & $(3)$ & $(4)$ \\
& $\begin{array}{l}\text { Change in happi- } \\
\text { ness Wave 2-Wave }\end{array}$ & $\begin{array}{l}\text { Change in happi- } \\
\text { ness Wave 2-Wave }\end{array}$ & $\begin{array}{l}\text { Change in happi- } \\
\text { ness Wave 2 - Wave } \\
1\end{array}$ & $\begin{array}{l}\text { Change } \\
\text { in happi- } \\
\text { ness Wave } \\
\text { 2-Wave 1 }\end{array}$ \\
\hline $\begin{array}{l}\text { Expectations labor market }(\text { Wave 2-Wave 1) } \\
\text { Negative change (peak- }\end{array}$ & $-1.237 * * *$ & Reference & -0.068 & -0.305 \\
worse) & $(0.432)$ & & $(0.357)$ & $(0.919)$ \\
No change (worse- & $-1.169 * * *$ & 0.068 & Reference & -0.236 \\
worse) & $(0.383)$ & $(0.357)$ & & $(0.892)$ \\
Positive change (worse- & -0.933 & 0.305 & 0.236 & Reference \\
peak) & $(0.924)$ & $(0.919)$ & $(0.892)$ & 0.933 \\
No change (peak-peak) & Reference & $1.237 * * *$ & $1.169 * * *$ & $(0.924)$ \\
& & $(0.432)$ & $(0.383)$ & Yes \\
Control variables & Yes & Yes & Yes & 250 \\
Observations & 250 & 250 & 250 & 0.305 \\
R-squared & 0.305 & 0.305 & 0.305 & \\
\hline
\end{tabular}

Robust standard errors in parentheses

$* * * p<0.01, * * p<0.05, * p<0.1$

\subsubsection{Changing Expectations over Time}

Finally, we examine whether holding consistently positive expectations before and after the announcement of the referendum drive the resilience-generating effects of expectations. Table 5 shows the OLS estimates of a regression on changes in well-being between Waves 1 and 2 taking in changes in expectations. As already mentioned in the methodology section, we use due to the unavailability of the other expectations measures in wave 2 and beyond, an alternative indicator for expectations, based on the question: "Some analysts say that the impact of the economic crisis on the job market has already reached its peak and things will recover little by little. Others, on the contrary, say that the worst is still to come. Which of these two statements is closer to your opinion? (1) The impact of the crisis on jobs has already reached its peak. (2) The worst is still to come. (3) Don't know". ${ }^{14}$ Although a neutral category is lacking, we are able to gauge whether respondents' expectations become more positive [from (2) to (1)], become more negative [from (1) to (2)] or stay the same. Overall, $5.6 \%$ of the respondents indicate more positive expectations and $22.8 \%$ of the respondents indicate more negative expectations. The percentages of respondents who held consistently positive and consistently negative expectations between Wave 1 and Wave 2 are 19.6 and 52\% respectively.

Our results indeed show that the people who held consistently positive expectationsbefore and after the announcement of the referendum-experienced the smallest decline in subjective well-being in the wake of the referendum. However, people who switched from positive to negative expectations experienced a decline in well-being that was as strong as the decline experienced by people who held consistently negative expectations. Compared

\footnotetext{
${ }^{14}$ A limited number of respondents (11.9\%) filled out 'Don't know' in either Wave 1 or Wave 2. For the analysis they were omitted from the common sample, reducing the common sample from 284 to 250 .
} 
to respondents who were consistently positive, respondents who shifted to negative or were consistently negative experienced an additional decline of $0.9-1.2$ points on the $0-10$ happiness scale. Our conclusions hold when re-estimating the model using the Lewbel estimator (see Table 13 in "Appendix 2").

\section{Summary}

At present day, limited attention has been devoted to the resilience-generating capacities of positive expectations in the wake of adverse events. In this paper, we use high-frequency panel data to assess the subjective well-being impact of the stress and anxiety generated by an adverse event, the announcement of the Greek bailout referendum in July 2015. Our analysis shows that the announcement of the Greek bailout referendum affected wellbeing levels considerably, most likely by creating anxiety and stress within the population. Moreover, our results show that positive expectations-and maintaining positive expectations-have resilience-generating capacities for subjective well-being. Individuals with better expectations before the referendum announcement experienced smaller decreases in subjective well-being and adapted quicker to this adverse event than individuals who held negative expectations regarding the future. In addition, we find that it are positive expectations rather than the lack of negative expectations drive the resilience-generating effects.

The results support the view that positive expectations dispositionally and even as a mindset can be a source of resilience that allows individuals to cope and adapt quicker to adverse events. Indeed, additional analyses emphasize the importance of the persistence of these expectations. Hence, people who have a more positive outlook on life are particularly more resilient in times of crisis.

\section{Discussion}

Our finding that positive expectations - and maintaining positive expectations-have resilience-generating capacities for subjective well-being fits in the broader positive psychology literature on psychological capital and subjective well-being (Fredrickson et al. 2003). In this literature, optimism and hope-which can be linked to positive expectations-are perceived as a potential mechanism through which resilience can be attained. In other words, optimism and hope would ensure that people can respond with more resilience in negative situations and thus experience fewer negative consequences of setbacks (Atkinson et al. 2009). In this regard, our study confirms previous studies that found that positive expectations buffer well-being in the face of difficult circumstances (Fredrickson et al. 2003; Pinquart et al. 2007; Scheier et al. 1989). In this regard, our study also underline the relationship between hope, optimism and resilience that has been extensively studied in the psychological literature (e.g., Ong et al. 2006; Youssef and Luthans 2007; Segovia et al. 2012).

More generally, the findings in our study are also in line with the happiness economics literature that has examined the relationship between positive expectations and subjective well-being. In this regard, Senik (2008) found that better expectations with regards to economic wealth positively influence life satisfaction and subjective health in Russia. Similarly, Frijters et al. (2012), Knight and Gunatilaka (2010), and Gao and Smyth (2011) found that positive income expectations have a positive effect on people's life satisfaction in China. Other economic studies have also found a positive relationship between positive 
health expectations and happiness (Foster et al. 2012) and positive expectations about life in general and life satisfaction (De Juan et al. 2014).

Our study also showed that it is particularly important to have persistent positive expectations to generate resilience. In this regard, research in economics and psychology has also shown that experienced utility is dependent on past expectations and the extent to which these expectations have been realized (Stutzer 2004; Easterlin 2001). Where the satisfaction of past positive expectations positively influences current experienced utility, unmet past positive expectations can have a negative effect on current experienced utility (Loomes and Sugden 1986; Barazzetta 2015). In case of an adverse event, past positive expectations can result in disillusionment and subsequent declining well-being levels (Golub et al. 2009). For instance, students who predict high performance in their exams also experience higher disappointment when poorly graded (Sweeny and Shepperd 2010).

\section{Limitations and Future Research}

Although the topic is beyond the scope of this paper, further research should examine the precise mechanisms that might shape expectations during adverse events and their connection with experienced utility. Although the literature suggests that the tendency to have positive or negative expectations has a strong genetic basis and is generally stable (Hecht 2013; Moser et al. 2014), expectations can also be shaped by external stimuli. We capture deviations in labor market expectations before and after the stressful event and find that negative changes in expectations predict larger declines in happiness and slower recovery to initial levels. Along different lines, future research can measure different aspects of hope and optimism that may act as psychological capital in the wake of stressful events. Recent research by Burger et al. (2018), for example, mention different aspects and sources of optimism and hope that can be relevant in this context.

Methodologically, we relied on a single item measure of life satisfaction which is potentially limited. Although past research has utilized this method in large scale studies to successfully differentiate the extent objective characteristics such as income is related to life satisfaction (e.g., Jebb et al. 2018), the use of a single item is generally less reliable than multi-item scales which may attenuate effects (see Diener et al. 2013). However, recent research comparing single-item life satisfaction to multi-item life satisfaction scales from three large samples (total $n>16,000)$ show substantial convergence $(r=.62-.64)$ and, more importantly, did not show systematically different correlations with outcomes (i.e., average difference of .001-.005) (Cheung and Lucas 2014).

Additionally, our findings suggest the presence of the phenomenon of adaptation, but we are unable to observe complete recovery to the initial happiness levels, mainly because of the relatively short time frame for data collection. In this regard, future research should collect data for longer time periods in the wake of adverse events in order to study whether complete adaptation takes place.

Considering the high-frequency data used in our analysis, further research is needed to consider to the effect of the exogenous event on different age groups and on the general population; university students might be a special group and the Greek bailout referendum might have affected them somewhat differently compared to the general population. Indeed, much of social scientific research has relied on student samples which has been shown through meta-analyses to be less homogenous compared to broader adult samples (see Peterson 2001). At the same time, student samples can still be valid in showcasing the 
impact of a phenomenon-even if there is no generalization beyond the student population given that their well-being is in itself important. Although we suspect that it is not likely that our main findings would change considerably when more representative samples are employed, especially given the magnitude of the found effects (as well as wide coverage of the event by the media), additional research is needed to verify this claim.

Acknowledgements Support by the Goldschmeding Foundation for People, Work and Economy (project 'Hope as an Incentive') is acknowledged by Martijn Burger. Support by JPI Urban Europe project 'Resilient Cities: Industrial Network and Institutional perspectives on Economic Growth and Well-Being (Grant 43813-406)' is acknowledged by Spyridon Stavropoulos.

Open Access This article is distributed under the terms of the Creative Commons Attribution 4.0 International License (http://creativecommons.org/licenses/by/4.0/), which permits unrestricted use, distribution, and reproduction in any medium, provided you give appropriate credit to the original author(s) and the source, provide a link to the Creative Commons license, and indicate if changes were made.

\section{Appendix 1}

See Tables 6, 7, 8 and 9.

Table 6 Description of variables

\begin{tabular}{|c|c|c|}
\hline Variable & Exact question (Original) & Response \\
\hline \multirow[t]{6}{*}{ Expectations } & $\begin{array}{l}\text { What are your expectations for the year to come } \\
\text { will the next } 12 \text { months be better, worse or the } \\
\text { same, when it comes to...? }\end{array}$ & \\
\hline & Life in general & Same/better/worse \\
\hline & The financial situation of household & Same/better/worse \\
\hline & Your personal job situation & Same/better/worse \\
\hline & Employment situation in Greece & Same/better/worse \\
\hline & Economic situation in Greece & Same/better/worse \\
\hline $\begin{array}{l}\text { Expectations regarding } \\
\text { labor market condi- } \\
\text { tions }\end{array}$ & $\begin{array}{l}\text { "Some analysts say that the impact of the } \\
\text { economic crisis on the job market has already } \\
\text { reached its peak and things will recover little by } \\
\text { little. Others, on the contrary, say that the worst } \\
\text { is still to come. Which of the two statements is } \\
\text { closer to your opinion? }\end{array}$ & $\begin{array}{l}\text { (1) The impact of the crisis } \\
\text { on jobs has already reached } \\
\text { its peak } \\
\text { (2) The worst is still to come } \\
\text { (3) (DK)" }\end{array}$ \\
\hline Happiness & $\begin{array}{l}\text { Taking all things together, how happy would you } \\
\text { say you are? Please use this picture }\end{array}$ & $\begin{array}{l}1 \text { Not at all happy-10 Very } \\
\text { happy }\end{array}$ \\
\hline Gender & Are you... & 0 Male 1 Female \\
\hline \multicolumn{3}{|l|}{ Age } \\
\hline Marital status & $\begin{array}{l}\text { Could you indicate which corresponds best to } \\
\text { your own current situation? }\end{array}$ & $\begin{array}{l}\text { In a relationship, Married, } \\
\text { Single, Separated }\end{array}$ \\
\hline Living with: & $\begin{array}{l}\text { Could you indicate which corresponds best to } \\
\text { your own current situation? }\end{array}$ & $\begin{array}{l}0 \text { - I live with my parents } \\
\text { (same household) } \\
1 \text { - I live in a separately of } \\
\text { my parents (in a different } \\
\text { household) }\end{array}$ \\
\hline $\begin{array}{l}\text { Amount of monthly } \\
\text { expenses }\end{array}$ & $\begin{array}{l}\text { What is the amount of total monthly expenses you } \\
\text { make (IN EUROS)? }\end{array}$ & 0-299, 300-500, Above 500 \\
\hline
\end{tabular}


Table 6 (continued)

\begin{tabular}{|c|c|c|}
\hline Variable & Exact question (Original) & Response \\
\hline Health: suffer & $\begin{array}{l}\text { Do you suffer from a chronic physical or mental } \\
\text { health problem which affects you in your daily } \\
\text { life? }\end{array}$ & $0-$ No, $1-$ Yes \\
\hline $\begin{array}{l}\text { Frequency meeting } \\
\text { with friends }\end{array}$ & $\begin{array}{l}\text { How often do you meet socially with friends, rela- } \\
\text { tives or work colleagues? }\end{array}$ & $\begin{array}{l}\text { Every day/several times } \\
\text { per week, once per week/ } \\
\text { several times per month, } \\
\text { once per month/less than a } \\
\text { month/never }\end{array}$ \\
\hline Trust people & $\begin{array}{l}\text { Please tell me on a score of } 0-10 \text {, where } 0 \text { means } \\
\text { you can't be too careful and } 10 \text { means that most } \\
\text { people can be trusted. }\end{array}$ & $\begin{array}{l}0 \text { You can't be too careful } \\
\text { with people } \\
10 \text { Most people can be } \\
\text { trusted }\end{array}$ \\
\hline Voting behavior & $\begin{array}{l}\text { Which political party did you vote in the last } \\
\text { election? }\end{array}$ & Other, Syriza, Denied, \\
\hline Religion & $\begin{array}{l}\text { Regardless of whether you belong to a particular } \\
\text { religion, how religious would you say you are? }\end{array}$ & Non-religious, Religious \\
\hline \multicolumn{3}{|l|}{ Personality traits ${ }^{\mathrm{a}}$} \\
\hline $\begin{array}{l}\text { Neuroticism, extraver- } \\
\text { sion, openness, } \\
\text { agreeableness, con- } \\
\text { scientiousness }\end{array}$ & Big Five & $0-12$ \\
\hline University & In which University are you studying? & $\begin{array}{l}\text { Other, Aristotle, Patras, } \\
\text { Piraeus, Macedonias }\end{array}$ \\
\hline Department & In which department are you studying? & Open ended \\
\hline
\end{tabular}

${ }^{\text {a }}$ Indexes were created for all four dimensions using the following questions on whether one seems himself as someone who...: Neuroticism $(N)(1)$ worries a lot, (2) gets nervous easily, (3) remains calm in tense situations (recoded), Extraversion (E) (1) Is talkative, (2) (3) Is outgoing, sociable, (4) Is reserved (recoded), Openness to experience (O) (1) Is original, comes up with new ideas, (2) values artistic, aesthetic experiences, (3) has an active imagination, Agreeableness (A) (1) Is sometimes rude to others (recoded), (2) has a forgiving nature, (3) Is considerate and kind to almost everyone, Conscientiousness $(C)(1)$ Does a thorough job, (2) tends to be lazy(recoded), (3) Does things efficiently 
Table 7 Descriptive statistics of dependent and independent variables ${ }^{\mathrm{a}}$

\begin{tabular}{|c|c|c|c|c|c|}
\hline Variables & Obs & Mean & SD & Min & $\operatorname{Max}$ \\
\hline Differences in happiness $\mathrm{T} 2-\mathrm{T} 1$ & 284 & -1.98 & 2.41 & -10 & 5 \\
\hline Expectations index (5 domains $)^{a}$ & 284 & 2.07 & 0.48 & 1 & 3 \\
\hline Expectations regarding life in general-same ${ }^{a}$ & 284 & 0.39 & 0.49 & 0 & 1 \\
\hline Expectations regarding life in general-better ${ }^{\mathrm{a}}$ & 284 & 0.56 & 0.50 & 0 & 1 \\
\hline Differences in happiness T2-T4 & 162 & 1.04 & 1.99 & -4 & 8 \\
\hline Differences in happiness $\mathrm{T} 2-\mathrm{T} 3$ & 190 & 0.81 & 1.99 & -6 & 8 \\
\hline Differences in happiness T4 - T3 & 156 & 0.32 & 1.29 & -3 & 4 \\
\hline Differences in happiness $\mathrm{T} 3-\mathrm{T} 1$ & 194 & -1.10 & 1.97 & -7 & 5 \\
\hline Expectations regarding financial situation of household- - same $^{a}$ & 281 & 0.49 & 0.50 & 0 & 1 \\
\hline Expectations regarding financial situation of household- - better $^{a}$ & 281 & 0.27 & 0.44 & 0 & 1 \\
\hline Expectations regarding personal job situation-same ${ }^{a}$ & 281 & 0.48 & 0.50 & 0 & 1 \\
\hline Expectations regarding personal job situation- - better $^{\mathrm{a}}$ & 281 & 0.41 & 0.49 & 0 & 1 \\
\hline Expectations regarding employmentlsituation in Greece-same ${ }^{\mathrm{a}}$ & 270 & 0.47 & 0.50 & 0 & 1 \\
\hline Expectations regarding employmentlsituation in Greece-better ${ }^{a}$ & 270 & 0.17 & 0.38 & 0 & 1 \\
\hline Expectations regarding economiclsituation in Greece-same ${ }^{a}$ & 269 & 0.46 & 0.50 & 0 & 1 \\
\hline Expectations regarding economiclsituation in Greece-better ${ }^{a}$ & 269 & 0.10 & 0.30 & 0 & 1 \\
\hline
\end{tabular}

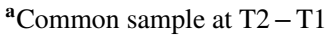

The variation in the sample size is due to the nature of the indexes. Separate expectations items were included in the indexes when (1) at least 4 items were available (for the 5 domain index) and (2) at least 3 items for the four item expectations index 


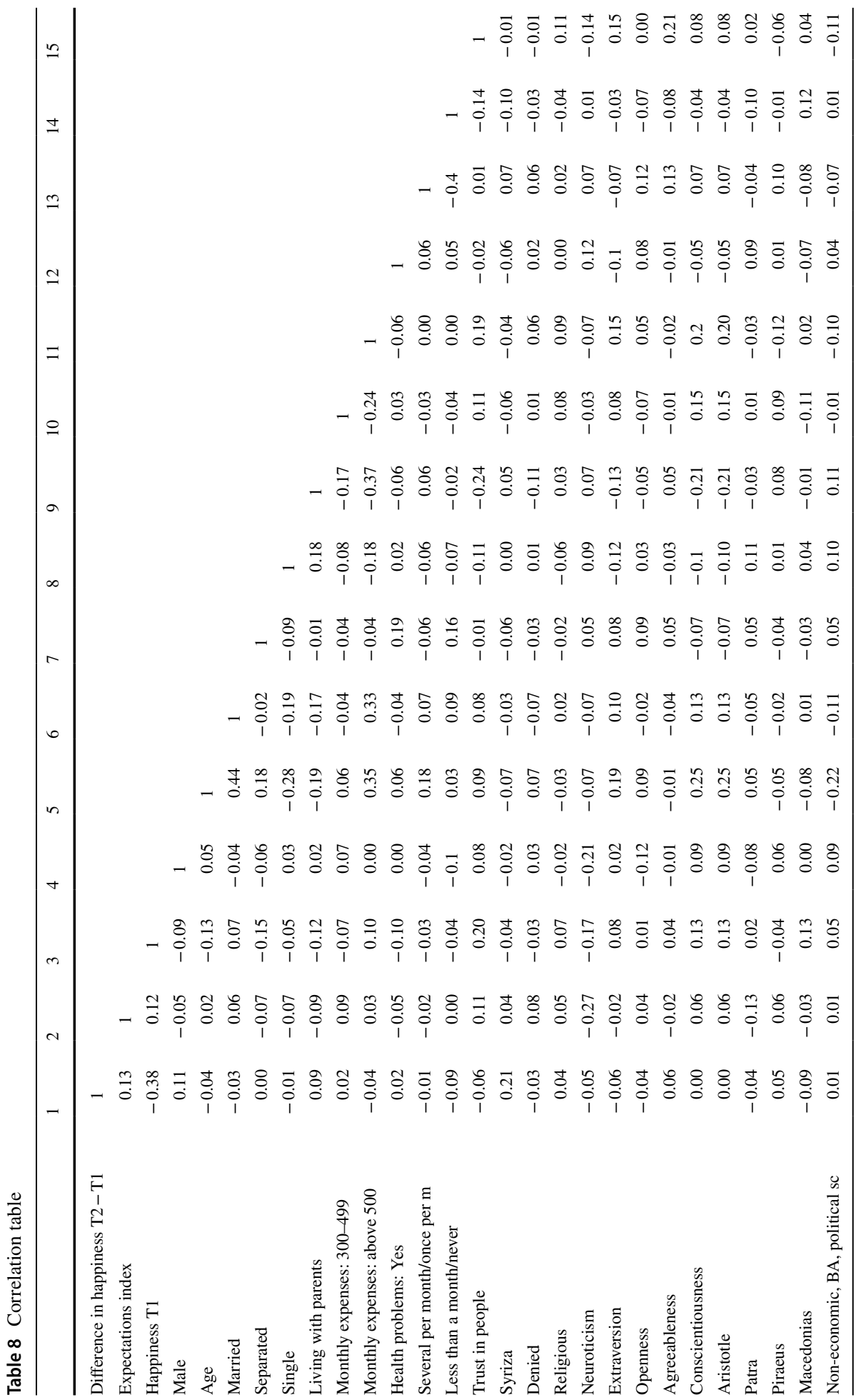




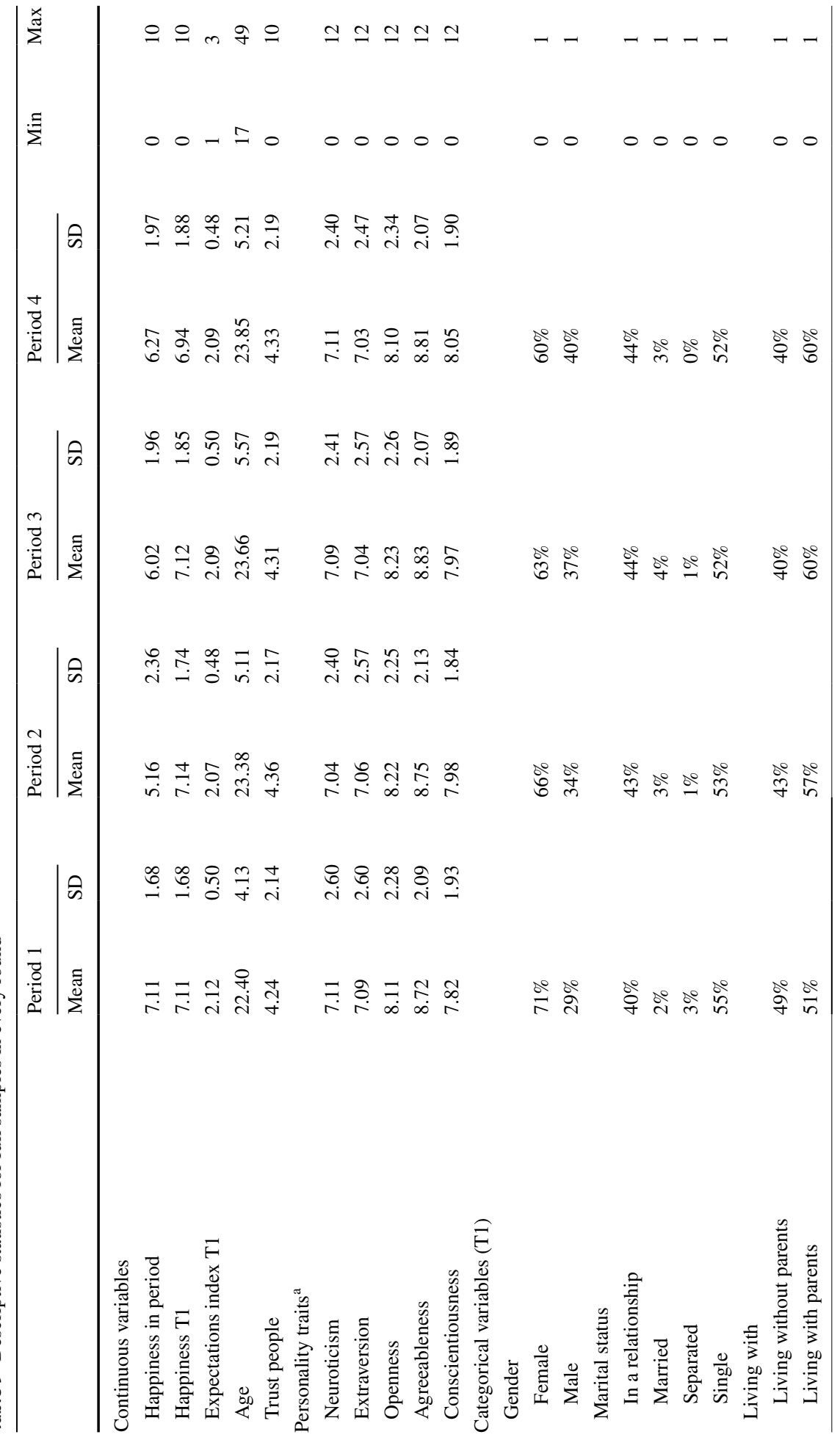




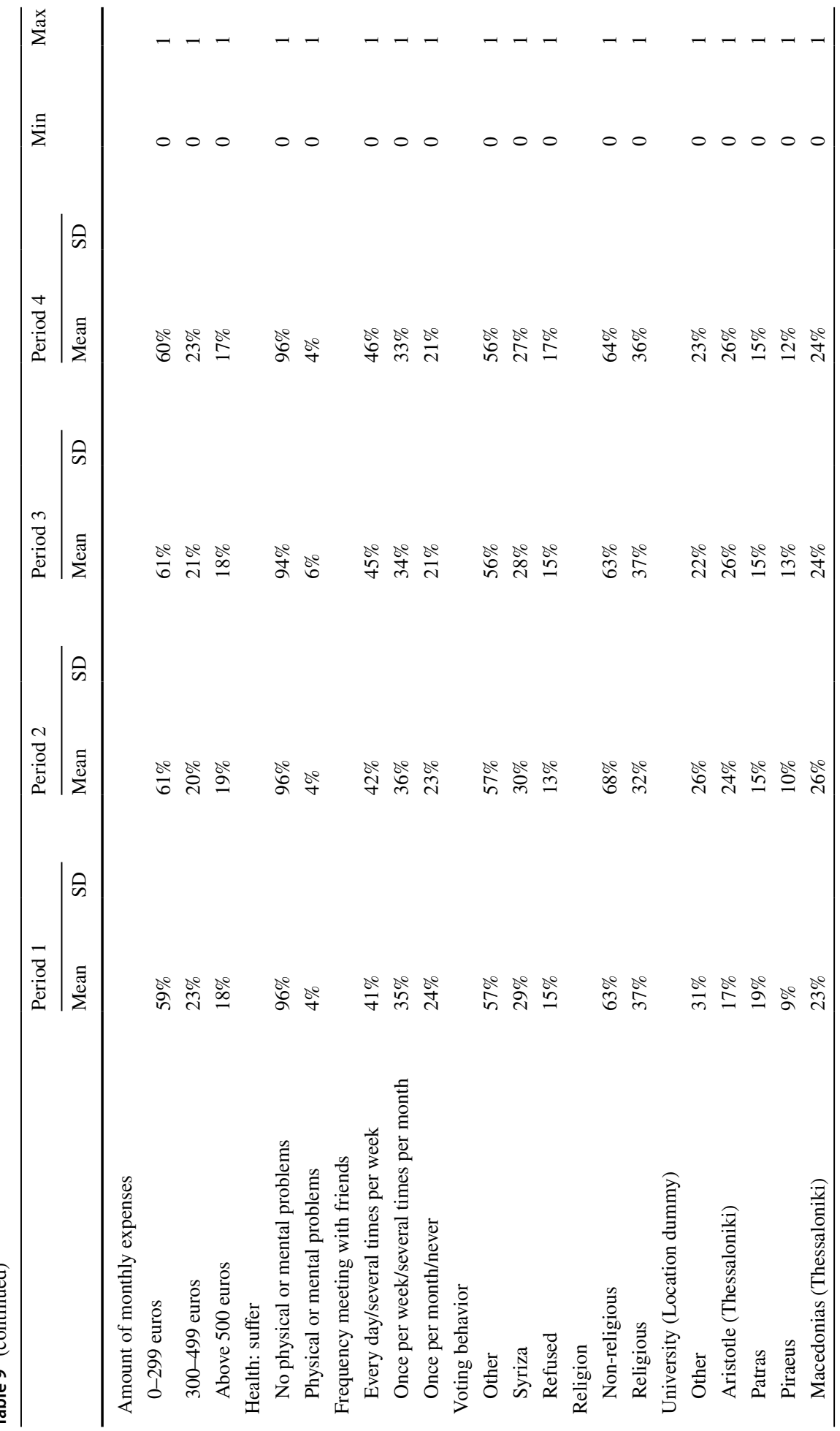




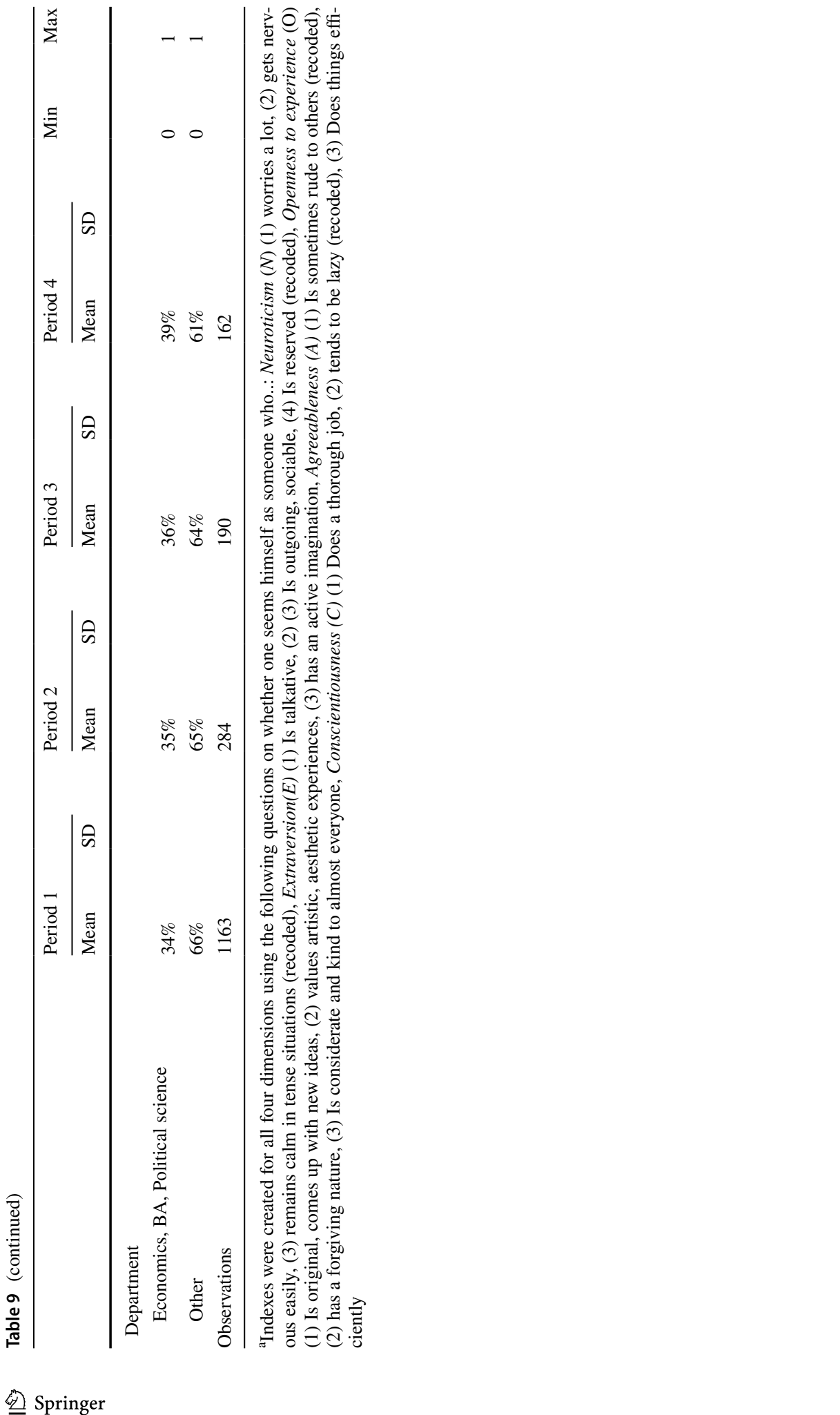




\section{Appendix 2: Additional Estimations}

See Tables 10, 11, 12 and 13.

Table 10 Expectations index and alternative time references-OLS estimates

\begin{tabular}{|c|c|c|c|}
\hline & $\begin{array}{l}\text { (1) } \\
\text { Change in happiness } \\
\text { Wave } 4 \text { - Wave } 3\end{array}$ & $\begin{array}{l}(2) \\
\text { Change in happiness } \\
\text { Wave } 3 \text { - Wave } 2\end{array}$ & $\begin{array}{l}\text { (3) } \\
\text { Change in hap- } \\
\text { piness Wave } \\
3 \text { - Wave } 1\end{array}$ \\
\hline Expectations index (5 domains) & $\begin{array}{l}0.441^{* *} \\
(0.220)\end{array}$ & $\begin{array}{l}0.695 * * * \\
(0.226)\end{array}$ & $\begin{array}{l}1.003 * * * \\
(0.253)\end{array}$ \\
\hline Male & $\begin{array}{l}-0.202 \\
(0.237)\end{array}$ & $\begin{array}{l}-0.275 \\
(0.268)\end{array}$ & $\begin{array}{l}-0.132 \\
(0.291)\end{array}$ \\
\hline Age & $\begin{array}{l}-0.018 \\
(0.026)\end{array}$ & $\begin{array}{l}-0.056^{*} \\
(0.031)\end{array}$ & $\begin{array}{l}-0.050 \\
(0.036)\end{array}$ \\
\hline Married & $\begin{array}{l}1.177 \\
(0.781)\end{array}$ & $\begin{array}{l}-0.829 \\
(1.155)\end{array}$ & $\begin{array}{l}-0.805 \\
(1.056)\end{array}$ \\
\hline Separated & - & $\begin{array}{l}-1.965^{*} \\
(1.173)\end{array}$ & $\begin{array}{l}-0.855 \\
(1.155)\end{array}$ \\
\hline Single & $\begin{array}{l}-0.241 \\
(0.189)\end{array}$ & $\begin{array}{l}-0.224 \\
(0.215)\end{array}$ & $\begin{array}{l}-0.209 \\
(0.242)\end{array}$ \\
\hline Live with my parents (same household) & $\begin{array}{l}0.299 \\
(0.238)\end{array}$ & $\begin{array}{l}-0.284 \\
(0.265)\end{array}$ & $\begin{array}{l}-0.159 \\
(0.277)\end{array}$ \\
\hline Month expenses: $300-499$ & $\begin{array}{l}0.177 \\
(0.269)\end{array}$ & $\begin{array}{l}0.106 \\
(0.284)\end{array}$ & $\begin{array}{l}0.147 \\
(0.343)\end{array}$ \\
\hline Month expenses: above 500 & $\begin{array}{l}0.175 \\
(0.357)\end{array}$ & $\begin{array}{l}0.262 \\
(0.352)\end{array}$ & $\begin{array}{l}0.196 \\
(0.426)\end{array}$ \\
\hline Physical or mental health problem: Yes & $\begin{array}{l}-0.432 \\
(0.317)\end{array}$ & $\begin{array}{l}-0.105 \\
(0.543)\end{array}$ & $\begin{array}{l}-0.069 \\
(0.431)\end{array}$ \\
\hline \multicolumn{4}{|l|}{ Frequency meeting friends } \\
\hline Once per week/several times a month & $\begin{array}{l}-0.410 \\
(0.254)\end{array}$ & $\begin{array}{l}-0.045 \\
(0.251)\end{array}$ & $\begin{array}{l}-0.177 \\
(0.303)\end{array}$ \\
\hline Once per month/never & $\begin{array}{l}0.227 \\
(0.259)\end{array}$ & $\begin{array}{l}-0.079 \\
(0.359)\end{array}$ & $\begin{array}{l}-0.327 \\
(0.345)\end{array}$ \\
\hline Trust in people & $\begin{array}{l}-0.001 \\
(0.058)\end{array}$ & $\begin{array}{l}0.072 \\
(0.063)\end{array}$ & $\begin{array}{l}0.041 \\
(0.068)\end{array}$ \\
\hline Voting behavior: Syriza & $\begin{array}{l}0.228 \\
(0.243)\end{array}$ & $\begin{array}{l}-0.154 \\
(0.266)\end{array}$ & $\begin{array}{l}0.397 \\
(0.295)\end{array}$ \\
\hline Voting behavior: denied & $\begin{array}{l}0.437 * \\
(0.246)\end{array}$ & $\begin{array}{l}-0.286 \\
(0.265)\end{array}$ & $\begin{array}{l}0.015 \\
(0.311)\end{array}$ \\
\hline Religious & $\begin{array}{l}0.394 * * \\
(0.183)\end{array}$ & $\begin{array}{l}-0.122 \\
(0.243)\end{array}$ & $\begin{array}{l}-0.335 \\
(0.257)\end{array}$ \\
\hline Neuroticism & $\begin{array}{l}-0.056 \\
(0.051)\end{array}$ & $\begin{array}{l}0.018 \\
(0.054)\end{array}$ & $\begin{array}{l}-0.023 \\
(0.060)\end{array}$ \\
\hline
\end{tabular}


Table 10 (continued)

\begin{tabular}{|c|c|c|c|}
\hline & (1) & (2) & (3) \\
\hline & $\begin{array}{l}\text { Change in happiness } \\
\text { Wave } 4-\text { Wave } 3\end{array}$ & $\begin{array}{l}\text { Change in happiness } \\
\text { Wave } 3 \text { - Wave } 2\end{array}$ & $\begin{array}{l}\text { Change in hap- } \\
\text { piness Wave } \\
3 \text { - Wave } 1\end{array}$ \\
\hline \multirow[t]{2}{*}{ Extraversion } & 0.032 & -0.047 & -0.057 \\
\hline & $(0.037)$ & $(0.047)$ & $(0.054)$ \\
\hline \multirow[t]{2}{*}{ Openness } & 0.018 & 0.018 & 0.012 \\
\hline & $(0.047)$ & $(0.049)$ & $(0.051)$ \\
\hline \multirow[t]{2}{*}{ Agreeableness } & 0.057 & 0.012 & 0.062 \\
\hline & $(0.048)$ & $(0.060)$ & $(0.063)$ \\
\hline \multirow[t]{2}{*}{ Conscientiousness } & 0.024 & 0.118 & 0.109 \\
\hline & $(0.067)$ & $(0.071)$ & $(0.070)$ \\
\hline \multirow[t]{2}{*}{ Non-economics, BA, political science } & 0.127 & 0.025 & -0.062 \\
\hline & $(0.204)$ & $(0.246)$ & $(0.283)$ \\
\hline \multirow[t]{2}{*}{ Happiness in start period } & $-0.281 * * *$ & $-0.592 * * *$ & $-0.620 * * *$ \\
\hline & $(0.066)$ & $(0.052)$ & $(0.080)$ \\
\hline Uni/location dummies & Yes & Yes & Yes \\
\hline \multirow[t]{2}{*}{ Constant } & 0.378 & $2.761 *$ & 1.629 \\
\hline & $(1.464)$ & $(1.473)$ & $(1.876)$ \\
\hline Observations & 156 & 190 & 194 \\
\hline R-squared & 0.304 & 0.510 & 0.399 \\
\hline
\end{tabular}

Robust standard errors in parentheses

$* * * p<0.01, * * p<0.05, * p<0.1$ 
Table 11 OLS estimates on relationship between change in happiness and different items of the expectations index (Wave 2-Wave 1)

\section{(1)}

(2)

(3)

(4)

(5)

Expectations regarding

Life in general: same

0.963

(0.730)

Life in general: better

$1.586^{* * *}$

$(0.708)$

Financial situation of household: same

Financial situation of household: better

Personal job situation: same

Personal job situation: better

Employment situation in country: same

Employment situation in country: better

Economic situation in country: same

Economic situation in country: better

Control variables

Observations

R-squared

Robust standard errors in parentheses

$* * * p<0.01 ; * * p<0.05 ; * p<0.10$
$0.915 * * *$

$(0.344)$

$0.665^{*}$

(0.394)

$1.058^{* *}$

$(0.522)$

$1.070^{* * *}$

(0.524)

$1.047 * * *$

(0.336)

0.593

(0.397)

0.422

(0.306)

0.736

(0.480)

Yes

269

0.259

-


Table 12 OLS estimates on relationship between change in happiness and different items of the expectations index (Wave $4-$ Wave 2)

(1)

(2)

(3)

(4)

Expectations regarding

Life in general: same

$-0.599$

(0.954)

Life in general: better

0.253

(0.930)

Financial situation of household: same $-0.002$

(0.332)

0.429

(0.398)

Personal job situation: same

Personal job situation: better

0.06

(0.472)

0.641

(0.472)

0.500

$(0.359)$

$0.970 * *$

(0.399)

Economic situation in country: same

(0.326)

$1.338 * * *$

Economic situation in country: better

(0.351)

$\begin{array}{llllll}\text { Observations } & 160 & 163 & 161 & 152 & 151 \\ \text { R-squared } & 0.516 & 0.504 & 0.507 & 0.532 & 0.526\end{array}$

Robust standard errors in parentheses

$* * * p<0.01 ; * * p<0.05 ; * p<0.10$

Table 13 Labor market expectations at Wave 1 and 2 and change in happiness-Lewbel estimates

\begin{tabular}{lllll}
\hline & $(1)$ & $(2)$ & $(3)$ & $(4)$ \\
& $\begin{array}{l}\text { Change in happiness } \\
\text { Wave 2- Wave 1 }\end{array}$ & $\begin{array}{l}\text { Change in happiness } \\
\text { Wave 2-Wave 1 }\end{array}$ & $\begin{array}{l}\text { Change in happiness } \\
\text { Wave 2 - Wave 1 }\end{array}$ & $\begin{array}{l}\text { Change in happiness } \\
\text { Wave 2 - Wave 1 }\end{array}$ \\
\hline $\begin{array}{l}\text { Expectations labor market } \\
\text { Negative change (peak- }-\end{array}$ & $-1.164 * * *$ & & \\
worse) & $(0.412)$ & Reference & -0.192 & -0.455 \\
No change (worse- & $-0.973^{* * *}$ & & $(0.376)$ & $(0.880)$ \\
worse) & $(0.355)$ & 0.192 & Reference & -0.264 \\
Positive change (worse- & -0.709 & $(0.376)$ & & $(0.859)$ \\
peak) & $(0.887)$ & 0.455 & 0.264 & Reference \\
No change (peak-peak) & Reference & $(0.880)$ & $(0.859)$ & 0.709 \\
& & $1.164 * * *$ & $0.973 * * *$ & $(0.887)$ \\
Control variables & Yes & $(0.412)$ & $(0.355)$ & Yes \\
Observations & 250 & Yes & Yes & 250 \\
R-squared & 0.305 & 250 & 250 & 0.305 \\
\hline
\end{tabular}

Robust standard errors in parentheses

$* * * p<0.01, * * p<0.05, * p<0.1$ 


\section{References}

Arampatzi, E., Burger, M. J., Stavropoulos, S., \& Van Oort, F. G. (2019). Subjective well-being and the 2008 recession in European regions: The moderating role of quality of governance. International Journal of Community Well-Being. https://doi.org/10.1007/s42413-019-00022-0.

Arampatzi, E., Burger, M. J., \& Veenhoven, R. (2015). Financial distress and happiness of employees in times of economic crisis. Applied Economics Letters, 22(3), 173-179.

Atkinson, P. A., Martin, C. R., \& Rankin, J. (2009). Resilience revisited. Journal of Psychiatric and Mental Health Nursing, 16(2), 137-145.

Barazzetta, M. (2015). The asymmetric effect of expectations on subjective well-being. ECINEQ WP 2015 $-374$

Benyamini, Y., \& Roziner, I. (2008). The predictive validity of optimism and affectivity in a longitudinal study of older adults. Personality and Individual Differences, 44, 853-864.

Boehm, J. K., Peterson, C., Kivimaki, M., \& Kubzansky, L. (2011). A prospective study of positive psychological well-being and coronary heart disease. Health Psychology, 3, 259-267.

Boyce, C. J., Wood, A. M., Banks, J., Clark, A. E., \& Brown, G. D. A. (2013). Money, well-being, and loss aversion: Does a loss in income have a greater effect on well-being than an equivalent income gain? Psychological Science, 24(12), 2557-2562.

Brissette, I., Scheier, M. F., \& Carver, C. S. (2002). The role of optimism in social network development, coping, and psychological adjustment during a life transition. Journal of Personality and Social Psychology, 82(1), 102-111.

Burger, M. J., Nullens, P., Van den Heuvel, S., \& Pleeging, E. (2018). Understanding and measuring hope: The interdisciplinary challenge of the hope barometer 1.0. In S. Van den Heuvel \& P. Nullens (Eds.), Driven by hope: Economics and theology in dialogue (pp. 3-20). Leuven: Peeters.

Carver, C. S., Scheier, M. F., \& Segerstrom, S. C. (2010). Optimism. Clinical Psychology Review, 30(7), 879-889.

Cheung, F., \& Lucas, R. E. (2014). Assessing the validity of single-item life satisfaction measures: Results from three large samples. Quality of Life Research, 23(10), 2809-2818.

Clark, A., \& Stancanelli, E. G. (2016). Individual well-being and the allocation of time before and after the Boston marathon terrorist bombing. IZA DP No. 9882, April 2016.

Cohn, M. A., Fredrickson, B. L., Brown, S. L., Mikels, J. A., \& Conway, A. M. (2009). Happiness unpacked: positive emotions increase life satisfaction by building resilience. Emotion, 9(3), 361-368.

Coupe, T. (2017). The impact of terrorism on expectations, trust and happiness-the case of the November 13 attacks in Paris, France. Applied Economics Letters, 24(15), 1084-1087.

De Juan, R., Mochón, F., \& Rojas, M. (2014). Expectations and happiness: Evidence from Spain. Journal of Social Research \& Policy, 5(2), 101-114.

De Neve, J. E., Ward, G., De Keulenaer, F., Van Landeghem, B., Kavetsos, G., \& Norton, M. I. (2018). The asymmetric experience of positive and negative economic growth: Global evidence using subjective well-being data. Review of Economics and Statistics, 100(2), 362-375.

Di Tella, R. D., MacCulloch, R. J., \& Oswald, A. J. (2003). The macroeconomics of happiness. Review of Economics and Statistics, 85(4), 809-827.

Diener, E., Inglehart, R., \& Tay, L. (2013). Theory and validity of life satisfaction scales. Social Indicators Research, 112(3), 497-527.

Easterlin, R. A. (2001). Income and happiness: Towards a unified theory. The Economic Journal, 111(473), 465-484.

European Commission, Brussels (2014). Eurobarometer 80.1 (2013). TNS Opinion, Brussels [producer]. GESIS Data Archive, Cologne. ZA5876 Data file Version 1.0.0. https://doi.org/10.4232/1.11881.

Foster, G., Frijters, P., \& Johnston, D. W. (2012). The triumph of hope over disappointment: A note on the utility value of good health expectations. Journal of Economic Psychology, 33(1), 206-214.

Fredrickson, B. L., Tugade, M. M., Waugh, C. E., \& Larkin, G. R. (2003). What good are positive emotions in crisis? A prospective study of resilience and emotions following the terrorist attacks on the United States on September 11th, 2001. Journal of Personality and Social Psychology, 84(2), 365.

Frey, B. S., Luechinger, S., \& Stutzer, A. (2009). The life satisfaction approach to valuing public goods: The case of terrorism. Public Choice, 138(3), 317-345.

Frijters, P., Liu, A. Y., \& Meng, X. (2012). Are optimistic expectations keeping the Chinese happy? Journal of Economic Behavior \& Organization, 81(1), 159-171.

Gao, W., \& Smyth, R. (2011). What keeps China's migrant workers going? Expectations and happiness among China's floating population. Journal of the Asia Pacific Economy, 16(2), 163-182. 
Goebel, J., Krekel, C., Tiefenbach, T., \& Ziebarth, N. R. (2015). How natural disasters can affect environmental concerns, risk aversion, and even politics: Evidence from Fukushima and three European countries. Journal of Population Economics, 28(4), 1137-1180.

Golub, S. A., Gilbert, D. T., \& Wilson, T. D. (2009). Anticipating one's troubles: The costs and benefits of negative expectations. Emotion, 9(2), 277.

Gosling, S. D., Rentfrow, P. J., \& Swann, W. B. (2003). A very brief measure of the Big-Five personality domains. Journal of Research in Personality, 37(6), 504-528.

Gudmundsdottir, D. G. (2013). The impact of economic crisis on happiness. Social Indicators Research, $110(3), 1083-1101$.

Hariri, J. G., Bjørnskov, C., \& Justesen, M. K. (2015). Economic shocks and subjective well-being: Evidence from a quasi-experiment. The World Bank Economic Review, 30(1), 55-77.

Hecht, D. (2013). The neural basis of optimism and pessimism. Experimental Nurobiology, 22(3), 173-199.

Jebb, A. T., Tay, L., Diener, E., \& Oishi, S. (2018). Happiness, income satiation, and turning points around the world. Nature Human Behavior, 2, 33-38.

Kahneman, D., \& Tversky, A. (1979). Prospect theory: An analysis of decision under risk. Econometrica: Journal of the Econometric Society, 47(2), 263-291.

Knight, J., \& Gunatilaka, R. (2010). Great expectations? The subjective well-being of rural-urban migrants in China. World Development, 38(1), 113-124.

Lewbel, A. (2012). Using heteroscedasticity to identify and estimate mismeasured and endogenous regressor models. Journal of Business \& Economic Statistics, 30(1), 67-80.

Loomes, G., \& Sugden, R. (1986). Disappointment and dynamic consistency in choice under uncertainty. The Review of Economic Studies, 53(2), 271-282.

Mak, W. W., Ng, I. S., \& Wong, C. C. (2011). Resilience: Enhancing well-being through the positive cognitive triad. Journal of Counseling Psychology, 58(4), 610-617.

Metcalfe, R., Powdthavee, N., \& Dolan, P. (2011). Destruction and distress: Using a quasi-experiment to show the effects of the September 11 attacks on mental well-being in the United Kingdom. The Economic Journal, 121(550), F81-F103.

Moser, J. S., Hartwig, R., Moran, T. P., Jendrusina, A. A., \& Kross, E. (2014). Neural markers of positive reappraisal and their associations with trait reappraisal and worry. Journal of Abnormal Psychology, 123(1), 91-105.

O'Connor, K. J. (2017). Who suffered most from the Great Recession? Happiness in the United States. RSF: The Russell Sage Foundation Journal of the Social Sciences, 3(3), 72-99.

Ong, A. D., Edwards, L. M., \& Bergeman, C. S. (2006). Hope as a source of resilience in later adulthood. Personality and Individual Differences, 41(7), 1263-1273.

Peale, N. V. (2007). The amazing results of positive thinking. New York: Simon and Schuster.

Peterson, R. A. (2001). On the use of college students in social science research. Journal of Consumer Research, 28, 450-461.

Pinquart, M., Fröhlich, C., \& Silbereisen, R. K. (2007). Change in psychological resources of younger and older cancer patients during chemotherapy. Psycho-Oncology, 16(7), 626-633.

Scheier, M. F., \& Carver, C. S. (1985). Optimism, coping, and health: Assessment and implications of generalized outcome expectancies. Health Psychology, 4(3), 219-247.

Scheier, M. F., \& Carver, C. S. (1992). Effects of optimism on psychological and physical well-being: Theoretical overview and empirical update. Cognitive Therapy and Research, 16, 201-228.

Scheier, M. F., Matthews, K. A., Owens, J. F., Magovern, G. J., Sr., Lefebvre, R. C., Abbott, R. A., \& Carver, C. S. (1989). Dispositional optimism and recovery from coronary artery bypass surgery: The beneficial effects on physical and psychological well-being. Journal of Personality and Social Psychology, 57, 1024-1040.

Scheier, M. F., Weintraub, J. K., \& Carver, C. S. (1986). Coping with stress: Divergent strategies of optimists and pessimists. Journal of Personality and Social Psychology, 51(6), 1257-1264.

Schimmack, U., \& Oishi, S. (2005). The influence of chronically and temporarily accessible information on life satisfaction judgments. Journal of Personality and Social Psychology, 89(3), 395-406.

Segovia, F., Moore, J. L., Linnville, S. E., Hoyt, R. E., \& Hain, R. E. (2012). Optimism predicts resilience in repatriated prisoners of war: A 37-year longitudinal study. Journal of Traumatic Stress, 25(3), $330-336$.

Senik, C. (2008). Is man doomed to progress? Journal of Economic Behavior \& Organization, 68(1), $140-152$.

Stutzer, A. (2004). The role of income aspirations in individual happiness. Journal of Economic Behavior \& Organization, 54(1), 89-109.

Sweeny, K., \& Shepperd, J. A. (2010). The costs of optimism and the benefits of pessimism. Emotion, 10(5), $750-753$. 
Taylor, S. E., Kemeny, M. E., Reed, G. M., Bower, J. E., \& Gruenewald, T. L. (2000). Psychological resources, positive illusions, and health. American Psychologist, 55(1), 99.

Tversky, A., \& Kahneman, D. (1991). Loss aversion in riskless choice: A reference-dependent model. The Quarterly Journal of Economics, 106(4), 1039-1061.

Veenhoven, R. (1984). Conditions of happiness. Dordrecht: Reidel.

Youssef, C. M., \& Luthans, F. (2007). Positive organizational behavior in the workplace: The impact of hope, optimism, and resilience. Journal of Management, 33(5), 774-800.

Publisher's Note Springer Nature remains neutral with regard to jurisdictional claims in published maps and institutional affiliations. 